\title{
Linear and Nonlinear Dynamics of the Turkish Trade Balance
}

\author{
Huseyin Karamelikli ${ }^{1}$ \\ ${ }^{1}$ Department of Economics, Karabuk University, Turkey \\ Correspondence: Huseyin Karamelikli, Department of Economics, Karabuk University, Turkey. E-mail: \\ huseyinkaramelikli@karabuk.edu.tr
}

Received: December 4, 2015

Accepted: December 25, $2015 \quad$ Online Published: January 25, 2016

doi:10.5539/ijef.v8n2p70

URL: http://dx.doi.org/10.5539/ijef.v8n2p70

\begin{abstract}
This study empirically analyses bilateral trade of Turkey with her main trade partners using monthly time series data over the period of 2000 to 2015 . J-curve theory and short-run dynamics of bilateral trade is tested by linear ARDL and Non-linear ARDL approaches. The empirical results indicate that there is no J-curve effect during short-run for United States and for France; it symmetrically exists to Germany and asymmetrically to United Kingdom. Also long-run relationship between exchange rate and trade balance has mixed results. Asymmetric long-run relationship between exchange rate and trade balance for United States exists where it is symmetrically most appropriate for Germany. In the other hand this study failed to verify any long-run relationship between exchange rate and trade balance for France and for United Kingdom.
\end{abstract}

Keywords: J-curve, Nonlinear ARDL, trade balance

\section{Introduction}

Exchange rate does have high importance in macroeconomic policies. Exchange rate can affect main macroeconomic variables (Korkmaz \& Bayır, 2015). This study concentrated on trade balance and the effects of real exchange rates on it. According to the economic theory, real evaluation of domestic money will worsen the trade balance. Also the improvement of trade balance is expected when foreign money is evaluated or domestic currency has been devaluated. But in short time it may be different. A change in exchange rate has price and volume effects on the flow of trade. Any real depreciation in domestic currency will cause more expensive imports and cheap export with relatively fixed amount of trade in short run. Then depreciation in domestic currency will lead to a temporary deterioration on the trade balance. After devaluation or depreciation of domestic currency, trade balance may change at inverse direction in short-run, due to adjustment lags. Hence it is called as J-curve effect and introduced by Magee (1973).

Despite the plethora of empirical researches in dynamics of exchange rate devaluation effects on trade balance, there is still uncertainty about long-run or short-run structure of J-curve. The empirical researches have mixed results. Rose and Yellen (1989), Rose (1990), Wilson and Tat (2001), Akbostanci (2004), Narayan (2004), Halicioglu (2008), Yazici and Klasra (2010) found no evidence of J-curve. But Demirden and Pastine (1995), Kale (2001), Jamilov (2013) and Batool et al. (2015) upheld J-curve phenomenon. Lal and Lowinger (2002) found evidence for some countries which is not valid for others. For a thorough literature review, consult Bahmani-Oskooee and Ratha (2004) and Bahmani-Oskooee and Hegerty (2010).

The majority of the research on J-curve has been conducted in a linear framework. However, many macroeconomic variables incorporate nonlinear properties (Falk, 1986). As trade balance and exchange rates are driven by the economic activity then nonlinearities is expected. Linear models may not be appropriate to J-curve phenomenon. If nonlinearities be existed in the model, the response of trade balance to positive shocks in exchange rates may be different from the response to negative shocks. Chen and Devereux (1994) found an important asymmetry between temporary import and export price shocks. They argued that asymmetry was ignored in theoretical and empirical works on the current account. Asymmetric relationship between current account and export and import prices has been studied by Holmes (2009), Mahdavi (2000) and Duasa (2009). Further Bahmani-Oskooee and Fariditavana (2015a, 2015b) used NARDL method for testing non-linear relationship between trade balance and real exchange rate.

The rest of the paper is organized as follows: In section 2, basic model, used data and its transformations and also the estimation technique of this paper will be presented. Section 3 analyzes the empirical results. Last 
section summarizes the paper with conclusions.

\section{Method}

Usually the difference between the value of total exports (X) and value of total imports (M) is defined as trade balance (TB). In this paper trade balance is used as ratio of export to imports (X/M). This type of variable has two advantages. Firstly previous type of variable may be negative and having logarithmic form would be impossible. Logarithmic model gives the Marshall-Lerner condition exactly rather than an approximation (Boyd, Caporale, \& Smith, 2001). Secondly it is insensitive to the units of measurement of export and import (Bahmani-Oskooee, 1991).

Following Onafowora (2003), this study use a commonly employed reduced-form model that trade balance for each country is a function of real exchange rate, domestic income and trade partner's income. It is assumed that trade balance has the long run relationship with the variables which represent Turkish industrial production index, partner industrial production index and real exchange rate:

$$
L T B_{t}=\alpha_{0}+\alpha_{1} L R E R_{t}+\alpha_{2} L_{P I P I_{t}}+\alpha_{3} L_{T I P I_{t}}+\epsilon_{t}
$$

Where $L T B_{t}$ is defied as $\ln \left(\frac{X}{M}\right)_{t}$ and $R E R_{t}$ is defined as $R E R_{t}=\frac{E_{t} P^{*}}{P_{t}}, \mathrm{E}$ is the nominal effective exchange rate, and $\mathrm{P}$ and $\mathrm{P} *$ are the domestic and foreign price levels respectively. LIPI and LTIPI represent partner country's income and Turkey's income in logarithmic forms respectively.

NARDL (nonlinear autoregressive distributed lag) approach is used in the study to estimate asymmetric effect of real exchange rate on the trade balance. The NARDL estimation method developed by Shin et al. (2014) and derived from the Pesaran et al. (2001) ARDL model. The asymmetric ARDL model combines the nonlinear long run relationship with the nonlinear error correction by using the partial sum decompositions. The asymmetric long-run relationship can be expressed as follows:

$$
y_{t}=\beta^{+} x_{t}^{+}+\beta^{-} x_{t}^{-}+u_{t}
$$

Where $x_{t}$ is a $k \times 1$ vector of regressors and decomposed as $x_{t}=x_{0}+x_{t}^{+}+x_{t}^{-}$where $x^{+}$and $x^{-}$are partial sum processes of positive and negative changes in $x_{t}$.

The ordinary error correction model (ECM) can be expressed as follows:

$$
\Delta L T B_{t}=\beta_{0}+\sum_{j=1}^{p} \beta_{1 j} \Delta L T B_{t-j}+\sum_{j=0}^{q} \beta_{2 j} \Delta L R E R_{t-j}+\sum_{j=0}^{m} \beta_{3 j} \Delta L I P I_{t-j}+\sum_{j=0}^{n} \beta_{4 j} \Delta L T I P I_{t-j}+\theta \epsilon_{t-1}+e_{t}
$$

Where $\Delta$ shows the first differences of the variables and $\varepsilon$ represents the error-correction term which are the OLS residuals series from the long-run cointegrating regression in Equation (1). The combination of Equation (1) and Equation (3) will be produce following ECM equation:

$$
\begin{aligned}
\Delta L T B_{t}= & \psi+\eta_{0} L T B_{t-1}+\eta_{1} L R E R_{t-1}+\eta_{2} L I P I_{t-1}+\eta_{3} L_{T I P I_{t-1}}+\sum_{j=1}^{p} \beta_{1 j} \Delta L T B_{t-j} \\
& +\sum_{j=0}^{q} \beta_{2 j} \Delta L R E R_{t-j}+\sum_{j=0}^{m} \beta_{3 j} \Delta L I P I_{t-j}+\sum_{j=0}^{n} \beta_{4 j} \Delta L T I P I_{t-j}+e_{t}
\end{aligned}
$$

Here $\psi=\beta_{0}-\theta \alpha_{0}, \eta_{0}=\theta, \eta_{1}=-\theta \alpha_{1}, \eta_{2}=-\theta \alpha_{2}, \eta_{3}=-\theta \alpha_{3}$. On the other hand $\eta_{0},-\frac{\eta_{1}}{\theta},-\frac{\eta_{2}}{\theta},-\frac{\eta_{3}}{\theta}$ are long run coefficients of LTB, LRER, LIPI and LTIPI variables, while $\beta_{1}, \beta_{2}, \beta_{3}, \beta_{4}$ are short run coefficients of the variables.

This study followed the approach developed by Schorderet $(2002,2003)$ and Shin et al. (2014) in order to determine asymmetric pass-through of real exchange rate on the trade balance. This approach requires that LRER variable is decomposed to the positive and negative shocks. Therefore, LRER $^{+}$and LRER $^{-}$are the partial sums of positive and negative changes in the LRER variable. These are calculated as follows:

$$
\begin{gathered}
L R E R_{t}^{+}=\sum_{i=1}^{t} \Delta L R E R_{i}^{+}=\sum_{i=1}^{t} \max \left(\triangle L R E R_{i}, 0\right) \\
L R E R_{t}^{-}=\sum_{i=1}^{t} \Delta L R E R_{i}^{-}=\sum_{i=1}^{t} \min \left(\triangle L R E R_{i}, 0\right)
\end{gathered}
$$

The long run relationship in Equation (1) can be rewritten as follows by considering Equation (5):

$$
L T B_{t}=\alpha_{0}+\alpha_{1}^{+} L R E E R_{t}^{+}+\alpha_{1}^{-} L R E R_{t}^{-}+\alpha_{2} L I P I_{t}+\alpha_{3} L T I P I_{t}+\epsilon_{t}
$$

Also by distinguishing long and short run asymmetric relationship Equation (4) can be rewritten as follows: 


$$
\begin{gathered}
\Delta L T B_{t}=\psi+\eta_{0} L T B_{t-1}+\eta_{1}^{+} L R E E R_{t-1}^{+}+\eta_{1}^{-} L R E R_{t-1}^{-}+\eta_{2} L I P I_{t-1}+\eta_{3} L_{T I P I_{t-1}}+\sum_{j=1}^{p} \beta_{1 j} \Delta L T B_{t-j}+ \\
\sum_{j=0}^{q}\left(\beta_{2 j}^{-} \Delta L R E R_{t-i}^{-}+\beta_{2 j}^{+} \Delta L R E R_{t-i}^{+}\right)+\sum_{j=0}^{m} \beta_{3 j} \Delta L I P I_{t-j}+\sum_{j=0}^{n} \beta_{4 j} \Delta L T I P I_{t-j}+e_{t}
\end{gathered}
$$

Where $\psi=\beta_{0}-\theta \alpha_{0}, \eta_{0}=\theta, \eta_{1}^{+}=-\theta \alpha_{1}^{+}, \eta_{1}^{-}=-\theta \alpha_{1}^{-}, \eta_{2}=-\theta \alpha_{2}, \eta_{3}=-\theta \alpha_{3}$ and $\alpha_{1}^{+}=-\frac{\eta_{1}^{+}}{\theta}, \alpha_{1}^{-}=-\frac{\eta_{1}^{-}}{\theta}$

are positive and negative long-run coefficients of the asymmetric real exchange rate, also $-\frac{\eta_{2}}{\theta}$ and $-\frac{\eta_{3}}{\theta}$ represents LIPI and LTIPI's long run coefficient respectively.

Equation (7) can be divided into long asymmetry and short run symmetry or long-run symmetry and short-run asymmetry by following Shin et al. (2014). These two equations were respectively presented in Equation (8) and (9).

If asymmetries exists only in the short-run following equation can be used:

$$
\begin{gathered}
\Delta L T B_{t}=\psi+\eta_{0} L T B_{t-1}+\eta_{1} L_{R E R_{t-1}}+\eta_{2} L_{L I P I_{t-1}}+\eta_{3} L T I P I_{t-1}+\sum_{j=1}^{p} \beta_{1 j} \Delta L T B_{t-j}+ \\
\sum_{j=0}^{q}\left(\beta_{2 j}^{-} \Delta L R E R_{t-i}^{-}+\beta_{2 j}^{+} \Delta L R E R_{t-i}^{+}\right)+\sum_{j=0}^{m} \beta_{3 j} \Delta L I P I_{t-j}+\sum_{j=0}^{n} \beta_{4 j} \Delta L T I P I_{t-j}+e_{t}
\end{gathered}
$$

On the other hand if asymmetries exists only in the long-run following equation can be used:

$$
\begin{gathered}
\Delta L T B_{t}=\psi+\eta_{0} L T B_{t-1}+\eta_{1}^{+} L R E R_{t-1}^{+}+\eta_{1}^{-} L R E R_{t-1}^{-}+\eta_{2} L I P I_{t-1}+\eta_{3} L T I P I_{t-1}+\sum_{j=1}^{p} \beta_{1 j} \Delta L T B_{t-j} \\
+\sum_{j=0}^{q} \beta_{2 j} \Delta L R E R_{t-j}+\sum_{j=0}^{m} \beta_{3 j} \Delta L I P I_{t-j}+\sum_{j=0}^{n} \beta_{4 j} \Delta L T I P I_{t-j}+e_{t}
\end{gathered}
$$

All the Equations (7), (8) and (9) present the long run cointegration between trade balance and the positive and negative components of the real exchange rate and symmetric components of LIPI and LTIPI.

The long-run cointegration can be determined by t-statistics by Banerjee et al. (1998) and F-statistics suggested by Pesaran et al. (2001). As the linear ARDL approach, Shin et al. (2014) propose the bounds test in order to determine the long-run asymmetric cointegration. The bounds test is used for jointly test all lagged level regressors. When t-statistics approach is preferred the null hypothesis is defined as $\eta_{0}=0$ against alternative hypothesis $\eta_{0}<0$. On the other hand null hypothesis is defined as $\eta_{0}=\eta_{1}=\eta_{2}=\eta_{3}=0$ against alternative hypothesis $\eta_{0} \neq 0$ or $\eta_{1} \neq 0$ or $\eta_{2} \neq 0$ or $\eta_{3} \neq 0$, when $F$ statistics approach is used. In the case of long-run asymmetry, null hypothesis would be $\eta_{0}=\eta_{1}{ }^{+}=\eta_{1}{ }^{-}=\eta_{2}=\eta_{3}=0$. Calculated Wald $\mathrm{F}$ value must be compared with the tabulated $\mathrm{F}$ values by Pesaran et al. (2001). The existence of the long-run symmetry is tested by Wald test of the null hypothesis of $\alpha_{1}^{+}=\alpha_{1}^{-}$. For checking short-run asymmetry, null hypothesis of $\sum_{i=0}^{q} \beta_{2 i}^{+}=\sum_{i=0}^{q} \beta_{2 i}^{-}$should be used. If null hypothesis of symmetry is rejected, our model will allow asymmetric effect. By rejecting null hypothesis of symmetry, asymmetric dynamic multiplier of change of $L R E E R^{+}$and $L R E E R^{-}$could be found respectively. The cumulative dynamic multiplier effects of $L R E E R^{+}$and $L R E E R^{-}$on LTB can be evaluated as follows :

$$
m_{h}^{+}=\sum_{i=0}^{h} \frac{\partial L T B_{t+i}}{\partial L R E R_{t}^{+}} ; m_{h}^{-}=\sum_{i=0}^{h} \frac{\partial L T B_{t+i}}{\partial L R E R_{t}^{-}}
$$

Note that as $h \rightarrow \infty$ then $m_{h}^{+} \rightarrow \alpha_{1}^{+}, m_{h}^{-} \rightarrow \alpha_{1}^{-}$, where $\alpha_{1}^{+}$and $\alpha_{1}^{-}$are the asymmetric long-run 
coefficients. The dynamic multipliers could capture the positive and negative shocks of real exchange rate on the trade balance from an initial equilibrium to the new equilibrium (Shin et al., 2014).

\section{Results}

In this study four major trade partner of Turkey has selected. Iran excluded from the study because of absence of industrial index data. Also Russia excluded because the main portion of trade belongs to energy agreements that seems to be insensitive to the changes of exchange rate in short run. Therefore this paper concentrates on Germany, France, United Kingdom and United States. Monthly data from January 2000 to May 2015 has used and all data has obtained from IMF dataset. Exports and import data are in US Dollar unit and consumer price indexes data has used for price variable in the model. Also industrial production index has used as proxy of national income for all countries.

All variables have been checked for their unit root degrees. And all of the variables have integrated with a degree smaller than two. The Equations numbered 4, 7, 8 and 9 have estimated for every country. Also to be sure about short run dynamics of error correction Equation (3) has estimated too. Max lag was selected as 12 and proper lag selected by 20736 iteration with using Schwarz criterion for each model of countries separately. Surprisingly proper lag for each model has calculated equal to other models. The Wald Test has applied for both long-run $\left(\mathrm{W}_{\mathrm{LR}}\right)$ and short-run $\left(\mathrm{W}_{\mathrm{SR}}\right)$ asymmetries. The long-run asymmetric model can be rejected if long-run symmetry hypothesis $\left(H_{0}: \alpha_{1}^{+}=\alpha_{1}^{-}\right)$is accepted. Also short-run asymmetry can be rejected when null hypothesis of short-run symmetry $\left(H_{0}: \sum_{i=0}^{q} \beta_{2 i}^{+}=\sum_{i=0}^{q} \beta_{2 i}^{-}\right)$is accepted.

Results for Germany, France, United Kingdom and United States are tabulated in Table 1 to 4.

Table 1. Empirical results for Germany

\begin{tabular}{|c|c|c|c|c|}
\hline & \multicolumn{2}{|c|}{ Long-run Symmetry } & \multicolumn{2}{|c|}{ Long-run Asymmetry } \\
\hline & $\begin{array}{l}\text { Short-run Symmetry: } \\
\text { Equation (4) }\end{array}$ & $\begin{array}{l}\text { Short-run Asymmetry: } \\
\text { Equation (8) }\end{array}$ & $\begin{array}{l}\text { Short-run Symmetry: } \\
\text { Equation (9) }\end{array}$ & $\begin{array}{l}\text { Short-run Asymmetry: } \\
\text { Equation (7) }\end{array}$ \\
\hline INTERSECT & -0.568865 & -0.542172 & 0.061668 & 0.133027 \\
\hline $\operatorname{LTB}(-1)$ & $-0.574892^{*}$ & $-0.601823^{*}$ & $-0.571148^{*}$ & $-0.598333 *$ \\
\hline LRER-(-1) & & & $0.215290 * *$ & $0.216469 * *$ \\
\hline LRER+(-1) & & & $0.274204 * *$ & $0.281678 * *$ \\
\hline LRER & $0.212730 * *$ & $0.213523 * *$ & & \\
\hline LIPI(-1) & 0.149930 & 0.129941 & 0.118441 & 0.094638 \\
\hline LTIPI(-1) & $-0.118836^{*}$ & $-0.110351^{*}$ & $-0.199646^{* *}$ & $-0.199526^{* *}$ \\
\hline$\Delta \operatorname{LTB}(-1)$ & $-0.290831^{*}$ & $-0.279039 *$ & $-0.295189^{*}$ & $-0.283504 *$ \\
\hline$\Delta$ LRER & $-0.461946^{* * *}$ & & $-0.454630 * * *$ & \\
\hline$\Delta$ LRER(-1) & 0.187611 & & 0.186879 & \\
\hline$\Delta$ LRER- & & $-1.017222 * *$ & & $-1.029041^{* *}$ \\
\hline$\Delta$ LRER- $(-1)$ & & -0.081144 & & -0.084404 \\
\hline$\Delta$ LRER + & & 0.005367 & & 0.030449 \\
\hline$\Delta$ LRER+ $(-1)$ & & 0.314881 & & 0.312217 \\
\hline$\Delta$ LIPI & -0.017902 & -0.009235 & -0.019840 & -0.010809 \\
\hline$\Delta \operatorname{LIPI}(-1)$ & $-0.544460^{*}$ & $-0.506300^{*}$ & $-0.516648 *$ & $-0.474404 *$ \\
\hline$\Delta \operatorname{LIPI}(-2)$ & $-0.702479^{*}$ & $-0.686720 *$ & $-0.676496^{*}$ & $-0.657539 *$ \\
\hline$\Delta \operatorname{LIPI}(-3)$ & $-0.434536^{* *}$ & $-0.432165^{* *}$ & $-0.409645^{* *}$ & $-0.404375^{* *}$ \\
\hline$\Delta \operatorname{LIPI}(-4)$ & $0.438516^{* *}$ & $0.445889 * *$ & $0.468526^{* *}$ & $0.479320^{* *}$ \\
\hline$\Delta \operatorname{LIPI}(-5)$ & 0.200432 & 0.239909 & 0.234072 & 0.278286 \\
\hline$\Delta$ LIPI(-6) & -0.199547 & -0.153437 & -0.167540 & -0.117053 \\
\hline$\Delta \operatorname{LIPI}(-7)$ & $0.320634^{* * *}$ & $0.346246 *$ & $0.356930 * *$ & $0.386920 * *$ \\
\hline$\Delta \operatorname{LIPI}(-8)$ & 0.112890 & 0.128551 & 0.141294 & 0.160155 \\
\hline$\Delta \operatorname{LIPI}(-9)$ & $-0.253558^{* *}$ & $-0.237450 * * *$ & $-0.240445^{* * *}$ & $-0.222480 * * *$ \\
\hline$\Delta$ LTIPI & $2.813269^{*}$ & $2.614680 *$ & $2.636567 *$ & $2.413977^{*}$ \\
\hline$\Delta$ LTIPI(-1) & $-1.640749^{* *}$ & $-1.740512^{* *}$ & $-1.714696^{* *}$ & $-1.824344^{*}$ \\
\hline F-statistic & $22.99381^{*}$ & $21.06905^{*}$ & $21.85793 *$ & $20.15624^{*}$ \\
\hline $\mathrm{R} 2$ & 0.738124 & 0.743051 & 0.739495 & 0.744725 \\
\hline Jarque-Bera & 2.372439 & 2.350057 & 2.472936 & 2.279830 \\
\hline
\end{tabular}




\begin{tabular}{lllll}
\hline Heteroskedasticity F & 1.152521 & 1.118999 & 1.100457 & 1.087615 \\
Bounds Values & $3.23-4.35$ & $3.23-4.35$ & $2.86-4.01$ & $2.86-4.01$ \\
F Bound & 11.32124 & 29.59557 & 9.208011 & 9.666315 \\
WLR & & 0.784873 & 0.963679 \\
WSR & & 2.430982 & & 2.556781 \\
ECM(-1) & $-0.529878^{*}$ & -0.554343 & $-0.529878^{*}$ & $-0.554343^{*}$ \\
\hline
\end{tabular}

Note. *,** and $* * *$ denote significance at $1 \%, 5 \%$ and $10 \%$ level, respectively.

Table 1 shows that computed F-statistic exceeds the upper critical bounds value, then Null hypothesis of no cointegration was rejected in all models. Also the null hypothesis of no asymmetry in long-run or short-run has been accepted. Therefore any asymmetry for Germany case is rejected and only symmetric cointegration model could be accepted. Coefficient of error correction term in Equation (3) is significant and valued between zero and minus one. Then error correction mechanism can accepted in the model. Also the results show that more than fifty percent of long-run shocks can be adjusted in just one month.

Symmetric model shows that there is a positive relationship between real exchange rate and trade balance in long-run. Turkey's industrial production index coefficient is significant but has negative long-run relationship with real exchange rate. Long-run coefficient of Germany's national income is positive but is not significant. Short-run results show that the sign of current lagged exchange rate is negative and statistically significant followed with positive but not statistically significant even at $10 \%$. Because of positive and significant long-run relationship between trade balance and exchange rate, J-curve phenomenon can be accepted for Turkey trade with Germany.

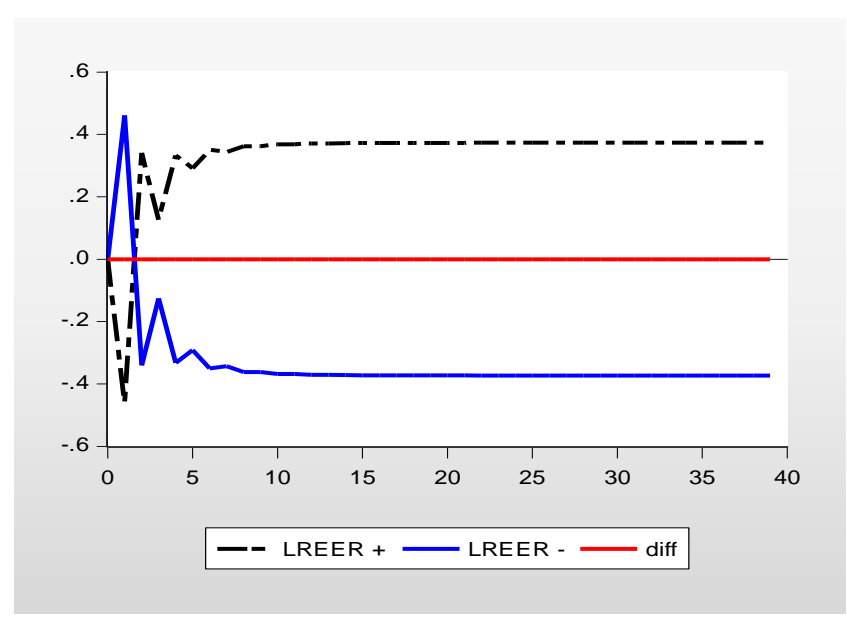

Figure 1. Turkey-Germany trade balance long-run \& short-run symmetry dynamic multipliers

Figure 1 reveals the pattern of dynamic adjustment in the symmetric case for Turkey trade with Germany. Short-run dynamics are able to show J-curve effect in very small period of time. Therefore J-curve effect was appeared symmetrical and as like as short-run coefficients of model shows only one month later it was passed on. Also this figure reveals that any increases (decrease) in real exchange rate temporally make trade balance decrease (increase) but in long-run it is reversal. 
Table 2. Empirical results for France

\begin{tabular}{|c|c|c|c|c|}
\hline & \multicolumn{2}{|c|}{ Long-run Symmetry } & \multicolumn{2}{|c|}{ Long-run Asymmetry } \\
\hline & $\begin{array}{l}\text { Short-run Symmetry: } \\
\text { Equation (4) }\end{array}$ & $\begin{array}{l}\text { Short-run Asymmetry: } \\
\text { Equation (8) }\end{array}$ & $\begin{array}{l}\text { Short-run Symmetry: } \\
\text { Equation (9) }\end{array}$ & $\begin{array}{l}\text { Short-run Asymmetry: } \\
\text { Equation (7) }\end{array}$ \\
\hline INTERSECT & -0.036671 & 0.071046 & 0.033127 & 0.037736 \\
\hline LTB $(-1)$ & $-0.324253^{*}$ & $-0.331242 *$ & $-0.324191^{*}$ & $-0.333124 *$ \\
\hline LRER-(-1) & & & 0.064697 & 0.060349 \\
\hline LRER+(-1) & & & 0.063580 & 0.092600 \\
\hline LRER & 0.065286 & 0.044276 & & \\
\hline LIPI(-1) & -0.083633 & -0.103321 & -0.085080 & -0.062238 \\
\hline LTIPI(-1) & 0.058147 & 0.055484 & 0.059413 & 0.018638 \\
\hline$\Delta \mathrm{LTB}(-1)$ & $-0.214813^{*}$ & $-0.219007^{*}$ & $-0.214897 *$ & $-0.216853^{*}$ \\
\hline$\Delta$ LRER & -0.089272 & & -0.089646 & \\
\hline$\Delta$ LRER(-1) & 0.064994 & & 0.065432 & \\
\hline$\Delta$ LRER- & & -0.622469 & & -0.626761 \\
\hline$\Delta$ LRER- (-1) & & 0.021829 & & 0.006546 \\
\hline$\Delta$ LRER + & & 0.361247 & & 0.384697 \\
\hline$\Delta$ LRER+ $+(-1)$ & & -0.020569 & & -0.035416 \\
\hline$\Delta$ LIPI & 0.075220 & 0.082815 & 0.074694 & \\
\hline$\Delta$ LIPI(-1) & -0.019527 & -0.004078 & -0.019035 & -0.017687 \\
\hline$\Delta$ LTIPI & $1.865089 * *$ & $1.667056^{* * *}$ & $1.866590 * *$ & $1.617153^{* * *}$ \\
\hline$\Delta$ LTIPI(-1) & -1.070919 & -1.022699 & -1.069005 & -1.075138 \\
\hline F-statistic & $6.037623^{*}$ & $5.230764 *$ & $5.502137 *$ & $4.838952 *$ \\
\hline $\mathrm{R} 2$ & 0.279739 & 0.288135 & 0.279739 & 0.288591 \\
\hline Jarque-Bera & 2.155427 & 1.486009 & 2.147945 & 1.662205 \\
\hline Heteroskedasticity F & 0.561729 & 0.794179 & 0.733725 & 0.901197 \\
\hline Bounds Values & $3.23-4.35$ & $3.23-4.35$ & $2.86-4.01$ & $2.86-4.01$ \\
\hline F Bound & 4.895637 & 10.99745 & 3.893636 & 4.032861 \\
\hline WLR & & & 0.000134 & 0.107486 \\
\hline WSR & & 0.612153 & & 0.642618 \\
\hline $\operatorname{ECM}(-1)$ & $-0.315960 *$ & $-0.319181 *$ & $-0.315960 *$ & -0.319181 \\
\hline
\end{tabular}

Note. $* * *$ and $* * *$ denote significance at $1 \%, 5 \%$ and $10 \%$ level, respectively.

Table 2 shows that cointegration exists for all models. As like as the Germany case the null hypothesis of no asymmetry in long-run or short-run has been accepted. Coefficient of error correction term in Equation (3) is suitable for error correction mechanism. In the case of trade with France any of the long-run coefficients of symmetric model are significant. Therefore exact value for long-run coefficients cannot be calculated. Short-run and long-run coefficients of exchange rate are not significant. This means that any long-run or short-run relationship between exchange rate and trade balance can be accepted.

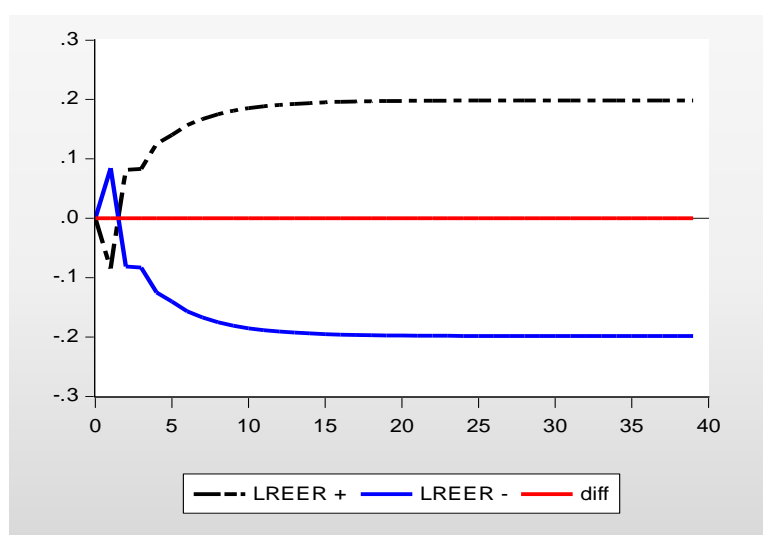

Figure 2. Turkey-France trade balance long-run \& short-run symmetry dynamic multipliers 
Figure 2 displays the pattern of dynamic adjustment in the symmetric case for France. Short-run dynamics are able to show J-curve effect in small period of time. But short-run and long-run coefficients of the model are not significant. Therefore on the contrary to Germany J-curve effect cannot be accepted for France.

Table 3. Empirical results for United Kingdom

\begin{tabular}{|c|c|c|c|c|}
\hline & \multicolumn{2}{|c|}{ Long-run Symmetry } & \multicolumn{2}{|c|}{ Long-run Asymmetry } \\
\hline & $\begin{array}{l}\text { Short-run Symmetry: } \\
\text { Equation (4) }\end{array}$ & $\begin{array}{l}\text { Short-run Asymmetry: } \\
\text { Equation (8) }\end{array}$ & $\begin{array}{l}\text { Short-run Symmetry: } \\
\text { Equation (9) }\end{array}$ & $\begin{array}{l}\text { Short-run Asymmetry: } \\
\text { Equation ( } 7 \text { ) }\end{array}$ \\
\hline INTERSECT & 0.760893 & 0.969709 & 2.307738 & 1.942625 \\
\hline LTB $(-1)$ & $-0.410733^{*}$ & $-0.433410^{*}$ & $-0.411762 *$ & $-0.433051^{*}$ \\
\hline LRER-(-1) & & & 0.042253 & 0.031825 \\
\hline LRER+(-1) & & & -0.108653 & -0.065008 \\
\hline LRER & 0.037233 & 0.026822 & & \\
\hline LIPI(-1) & -0.272803 & -0.328990 & $-0.694496 * *$ & $-0.594500 * * *$ \\
\hline LTIPI(-1) & $0.135959 *$ & $0.142440 *$ & $0.293286^{*}$ & $0.244153^{* *}$ \\
\hline$\Delta \mathrm{LTB}(-1)$ & $-0.194787 *$ & $-0.213446^{*}$ & $-0.204290^{*}$ & $-0.217079 *$ \\
\hline$\Delta$ LRER & -0.159739 & & -0.135348 & \\
\hline$\Delta$ LRER(-1) & 0.477731 & & $0.510277 * * *$ & \\
\hline$\Delta$ LRER- & & $-1.374275 * *$ & & $-1.289786 * *$ \\
\hline$\Delta$ LRER- $(-1)$ & & -0.447230 & & -0.359628 \\
\hline$\Delta$ LRER + & & $0.842215^{* * *}$ & & 0.797385 \\
\hline$\Delta$ LRER $+(-1)$ & & $1.151589^{* *}$ & & $1.127646^{* *}$ \\
\hline$\Delta$ LIPI & -0.143872 & -0.103454 & -0.284056 & -0.199694 \\
\hline$\Delta$ LIPI(-1) & 0.246781 & $0.367190 * * *$ & $0.399737 * * *$ & $0.454119^{* *}$ \\
\hline$\Delta$ LTIPI & $2.335759^{* *}$ & $1.561655^{* * *}$ & $2.457605^{*}$ & $1.695767^{* * *}$ \\
\hline$\Delta$ LTIPI(-1) & $-1.678593 * * *$ & $-2.002223 * *$ & $-1.479365 * * *$ & $-1.864897 * *$ \\
\hline F-statistic & $8.280525^{*}$ & $8.326833^{*}$ & 8.012065 & 7.859446 \\
\hline $\mathrm{R} 2$ & 0.347542 & 0.391853 & 0.361250 & 0.397182 \\
\hline Jarque-Bera & 0.156761 & 0.423587 & 0.118786 & 0.301294 \\
\hline Heteroskedasticity F & 0.805557 & 0.691623 & 1.092653 & 0.931087 \\
\hline Bounds Values & $3.23-4.35$ & $3.23-4.35$ & $2.86-4.01$ & $2.86-4.01$ \\
\hline F Bound & 7.731711 & 16.11661 & 7.01083 & 7.510116 \\
\hline WLR & & & $3.264615 * * *$ & 1.411955 \\
\hline WSR & & $11.02480 *$ & & $9.422932 *$ \\
\hline $\operatorname{ECM}(-1)$ & -0.412756 & $-0.433266^{*}$ & -0.412756 & $-0.433266^{*}$ \\
\hline
\end{tabular}

Note. *, ** and *** denote significance at $1 \%, 5 \%$ and $10 \%$ level, respectively.

Table 3 shows that null hypothesis of no cointegration was rejected in all models. Also in full asymmetry model (Equation no 7), the null hypothesis of no asymmetry at long-run has been accepted where it has rejected for short-run. Estimation of Equation (9) for UK reveals that long-run asymmetry has been accepted only at 10\% significance level. Also long-run error term coefficient is not significant in that model. Estimation of the model with short-run asymmetry and long-run symmetry that formulated in Equation (8), reveals that error correction model works. Also null hypothesis of short-run symmetry was rejected at $1 \%$ significant level. Therefore the best model for United Kingdom case is short-run asymmetric and long-run symmetric model. Despite to long-run positive relationship between exchange rate and trade balance with UK, relevant variables coefficient is not significant even at $10 \%$ of significance level. Short-run coefficients show that the sign of current and first lagged negative components of exchange rate is negative and statistically significant followed with negative but not statistically significant even at $10 \%$. The sign of current and first lagged positive components of exchange rate, both coefficients are positive and statistically significant. Based on economic theory it is expected that appreciation (negative components of exchange rate) cause temporary improve in trade balance. Here the study found that a short-run negative change in exchange rates makes trade balance improved where it is not true for positive changes of exchange rate. 


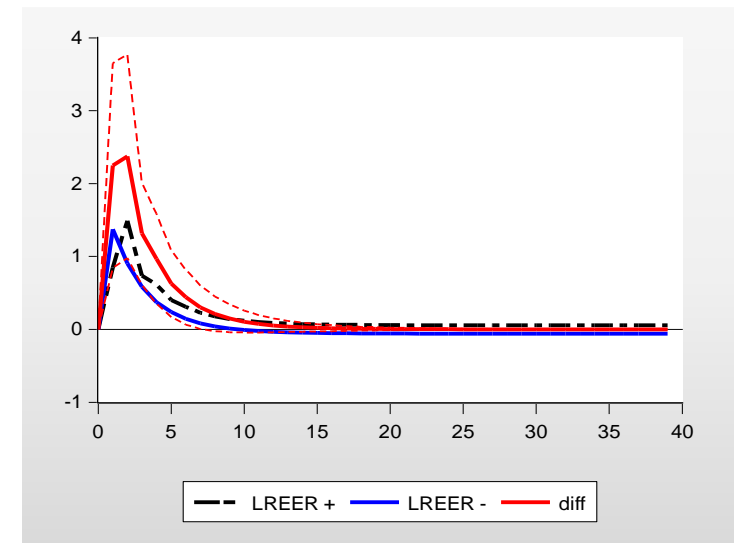

Figure 3. Turkey-United Kingdom trade balance long-run \& short-run symmetry dynamic multipliers

Figure 3 reveals that the pattern of dynamic adjustment in the long-run symmetry and short-run asymmetry is true for United Kingdom. Long-run relationship between trade balance and exchange rate is not statistically significant where at short-run there is an asymmetric path through exchange rate changes to trade balance in case of UK. A decrease in real exchange rate cause very quick increase in trade balance. Then short-run asymmetry is revealed from short-run dynamics of model. In case of UK, it can be said that J-curve is valid only at decreases of real exchange rate and there are not evidences about $\mathrm{J}$-curve phenomenon for increasing at exchange rate.

Table 4. Empirical results for United States of America

\begin{tabular}{|c|c|c|c|c|}
\hline & \multicolumn{2}{|c|}{ Long-run Symmetry } & \multicolumn{2}{|c|}{ Long-run Asymmetry } \\
\hline & $\begin{array}{l}\text { Short-run Symmetry: } \\
\text { Equation (4) }\end{array}$ & $\begin{array}{l}\text { Short-run Asymmetry: } \\
\text { Equation (8) }\end{array}$ & $\begin{array}{l}\text { Short-run Symmetry: } \\
\text { Equation (9) }\end{array}$ & $\begin{array}{l}\text { Short-run Asymmetry: } \\
\text { Equation (7) }\end{array}$ \\
\hline INTERSECT & -0.903210 & -1.492061 & -2.359323 & -2.518037 \\
\hline LTB $(-1)$ & $-0.164482 *$ & $-0.169490 *$ & $-0.251603^{*}$ & $-0.240090^{*}$ \\
\hline LRER-(-1) & & & $0.620602^{*}$ & $0.579809^{*}$ \\
\hline LRER+(-1) & & & $0.429916^{*}$ & $0.423384 *$ \\
\hline LRER & $0.431218^{*}$ & $0.423032 *$ & & \\
\hline LIPI(-1) & $0.431218^{*}$ & 0.272410 & 0.385077 & 0.446784 \\
\hline LTIPI(-1) & -0.022283 & -0.029148 & $0.214254^{* * * *}$ & 0.166069 \\
\hline$\Delta \mathrm{LTB}(-1)$ & $-0.571987 *$ & $-0.571814^{*}$ & $-0.508998^{*}$ & $-0.520191 *$ \\
\hline$\Delta$ LRER & $1.170435^{*}$ & & $1.252861^{*}$ & \\
\hline$\Delta$ LRER(-1) & -0.542846 & & -0.519964 & \\
\hline$\Delta$ LRER- & & 0.037789 & & 0.304905 \\
\hline$\Delta$ LRER- (-1) & & -1.084168 & & -0.973203 \\
\hline$\Delta$ LRER + & & $1.981859 *$ & & $1.905772 *$ \\
\hline$\Delta$ LRER $+(-1)$ & & -0.155176 & & -0.201601 \\
\hline$\Delta$ LIPI & -0.687067 & -0.323386 & -0.458601 & -0.199693 \\
\hline$\Delta$ LIPI(-1) & 0.711307 & 1.157666 & 0.763642 & 1.122085 \\
\hline$\Delta$ LTIPI & 1.874191 & 1.418139 & $1.924373^{* * *}$ & 1.539405 \\
\hline$\Delta$ LTIPI(-1) & -0.851732 & -0.990034 & -0.899248 & -1.005850 \\
\hline$\Delta$ LTIPI(-2) & & $-5.096513 *$ & $-4.946378^{*}$ & \\
\hline F-statistic & $11.66649 *$ & $10.51006^{*}$ & 11.31645 & $10.11027 *$ \\
\hline $\mathrm{R} 2$ & 0.474449 & 0.487102 & 0.486833 & 0.495049 \\
\hline Jarque-Bera & 1.913640 & 1.425281 & 1.558268 & 1.260808 \\
\hline Heteroskedasticity F & 0.417147 & 0.570330 & 0.428616 & 0.501993 \\
\hline Bounds Values & $3.23-4.35$ & $3.23-4.35$ & $2.86-4.01$ & $2.86-4.01$ \\
\hline F Bound & 4.452468 & 22.17882 & 4.432285 & 4.020291 \\
\hline WLR & & & $7.045266^{*}$ & $4.322778 * *$ \\
\hline WSR & & $3.828387 * * *$ & & 2.521687 \\
\hline $\operatorname{ECM}(-1)$ & -0.151308 & $-0.156653^{*}$ & $-0.151308^{*}$ & $-0.156653^{*}$ \\
\hline
\end{tabular}

Note. *, ** and *** denote significance at $1 \%, 5 \%$ and $10 \%$ level, respectively. 
Table 4 shows that long-run cointegration between variables exists in all models. In full asymmetry model (Equation no 7) the null hypothesis of no asymmetry at long-run has been rejected at 5\% significant level where null hypothesis of no short-run asymmetry in model accepted. So the full asymmetric model cannot be valid for US. Equation (8) model offer short-run asymmetry with long-run symmetry for real exchange rate. Null hypothesis of short-run symmetry can be rejected only at $10 \%$ significance level. Equation (9) has asymmetric behavior only at long-run. Therefore short-run symmetry with long-run asymmetry looks as the best model for US. The null hypothesis of symmetry at long-run is rejected in \%1 significance level. Also long-run error correction term coefficient is significant and appropriate to ECM in this model.

Both positive (depreciation) and negative (appreciation) components of exchange rate are significant at $1 \%$ level and both coefficients are positive. It can be concluded that there is long-run asymmetric relationship between exchange rate and trade balance for case of US. When exchange rates increases trade balance improves and when it decreases trade balance deteriorates. Positive coefficients of both components of exchange rates make results matched with theory at long-run. But it is not true for short-run. The sign of current and first lagged of exchange rate changes are positive and negative respectively that cannot approve short-run $\mathrm{J}$-curve.

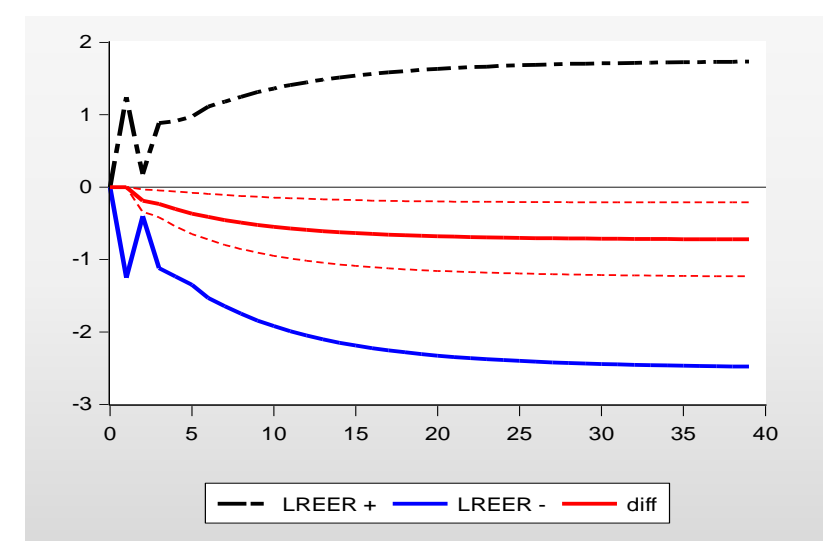

Figure 4. Turkey-United States of America trade balance long-run \& short-run symmetry dynamic multipliers

Figure 4 displays that the long-run asymmetry instead of short-run asymmetry. In short-run both increase and decrease have similar movements where in long-run differences grow rapidly. In the other word the gap between positive and negative shocks of exchange rate on trade balance is wider in long-run. The pattern of dynamic adjustment in the long-run asymmetry and short-run symmetry is explicit for United States. An increase in exchange rate will cause trade balance to grow but a decrease in exchange rate has deeper effect in long run.

\section{Conclusions}

In this study the short-run and long-run effects of real exchange rate on the trade balance in dynamic models has argued. Turkey's four major trade partners were selected and their monthly data has used to estimate symmetric and asymmetric models in short-run or long-run separately. This study found that there is cointegration between trade balance, exchange rate, domestic and partner incomes. Thus it can be said that our model is valid in long run. Also for all countries it revealed that error correction terms in accepted models are significant and have proper values.

Findings for each country are different respect to others. This study found that the symmetric model is the best fitted model for Germany and France. In the other hand short-run asymmetry for UK and long-run asymmetry for US are the rest fitted models.

Despite the existence of long-run cointegration for all models, exchange rate's long-run coefficient was significant only for Germany and United States. Long-run coefficients for both countries are as economic theory suggests, a real depreciation (appreciation) of the Turkish lira improves (declines) the Turkish trade balance. Thus, it can be concluded that the Marshall-Lerner condition has hold for Germany and United States cases in the long run.

J-curve phenomenon is valid only at short-run and investigating of multiple models revealed that it is true only for Germany and partially for UK. J-curve for United Kingdom is asymmetric and only with negative changes (depreciation) it can be observed. 
This paper revisits the J-curve using monthly data from Turkey and its main trade partners. This study finds that linear adjustment and nonlinear processes could be used for checking the J-curve effect. However, each approach has different results and using linear adjustment process should be wrong as much as using of nonlinear approche alone. Thus checking for long-run and short-run asymmetries is critical.

Long-run and positive relationship between exchange rate and trade balance found here then It is here by suggested that devaluation of exchange rate could improve the balance of payment of Turkey only at long-run and there may be reversed effects in short-run. Therefore Central bank of Turkey has to be vigilant towards its monetary policy. Policy makers must be aware about short-run outcomes of any shocks at exchange markets.

This paper revisits the J-curve effect using monthly data of Turkey and its main trade partners. Then the study finds that linear adjustment and nonlinear processes could be used for checking the J-curve effect. However, each approach has different results. this paper outcomes shows that linear adjustment could not be used solely. This is veridical for nonlinear approach too. Thus checking over long-run and short-run asymmetries is critical.

Long-run and positive relationship between exchange rate and trade balance found here suggests that devaluation of exchange rate can improve the balance of payment of Turkey only at long-run and there may be reversed effects in short-run. Therefore Central Bank of Turkey has to be vigilant about its monetary policies. Policy makers must be aware of short-run effects of any shocks at exchange markets.

\section{References}

Akbostanci, E. (2004). Dynamics of the trade balance: The turkish J-curve. Emerging Markets Finance and Trade, 40(5), 57-73. http://dx.doi.org/10.1080/1540496X.2004.11052584

Bahmani-Oskooee, M. (1991). Is there a long-run relation between the trade balance and the real effective $\begin{array}{llllll}\text { exchange rate of LDCs? Economics } & \text { Letters, }\end{array}$ http://dx.doi.org/10.1016/0165-1765(91)90206-Z

Bahmani-Oskooee, M., \& Fariditavana, H. (2015a). Nonlinear ARDL approach and the J-curve phenomenon. Open Economies Review. http://dx.doi.org/10.1007/s11079-015-9369-5

Bahmani-Oskooee, M., \& Fariditavana, H. (2015b). Nonlinear ARDL approach, asymmetric effects and the J-curve. Journal of Economic Studies, 42(3), 519-530. http://dx.doi.org/10.1108/JES-03-2015-0042

Bahmani-Oskooee, M., \& Hegerty, S. W. (2010). The J- and S-curves: A survey of the recent literature. Journal of Economic Studies, 37(6), 580-596. http://dx.doi.org/10.1108/01443581011086639

Bahmani-Oskooee, M., \& Ratha, A. (2004). The J-Curve: A literature review. Applied Economics, 36(13), 1377-1398. http://dx.doi.org/10.1080/0003684042000201794

Banerjee, A., Dolado, J., \& Mestre, R. (1998). Error-correction mechanism tests for cointegration in a single-equation framework. Journal of Time Series Analysis, 19(3), 267-283. http://dx.doi.org/10.1111/1467-9892.00091

Batool, S. A., Memood, T., \& Jadoon, A. K. (2015). What determines balance of payments: A case of Pakistan. Sukkur IBA Journal of Management and Business, 2(1), 47-70.

Boyd, D., Caporale, G. M., \& Smith, R. (2001). Real exchange rate effects on the balance of trade: Cointegration and the Marshall-Lerner condition. International Journal of Finance and Economics, 6(3), 187-200. http://dx.doi.org/10.1002/ijfe.157

Chen, L. L., \& Devereux, J. (1994). Import prices, export prices and the current account. Economics Letters, 44(4), 415-420. http://dx.doi.org/10.1016/0165-1765(94)90114-7

Demirden, T., \& Pastine, I. (1995). Flexible exchange rates and the J-curve: An alternative approach. Economics Letters, 48(3-4), 373-377. http://dx.doi.org/10.1016/0165-1765(94)00634-E

Duasa, J. (2009). Asymmetric cointegration relationship between real exchange rate and trade variables: The case of Malaysia (No. 14535).

Falk, B. (1986). Further evidence on the asymmetric behavior of economic time series over the business cycle. Journal of Political Economy, 94(5), 1096-1109. http://dx.doi.org/10.1016/0164-0704(91)90057-2

Halicioglu, F. (2008). The J-curve dynamics of Turkey: An application of ARDL model. Applied Economics, 40(18), 2423-2429. http://dx.doi.org/10.1080/00036840600949496

Holmes, M. J., \& Panagiotidis, T. (2009). Cointegration and asymmetric adjustment: Some new evidence concerning the behavior of the U.S. current account. The B.E. Journal of Macroeconomics, 9(1). 
http://dx.doi.org/10.2202/1935-1690.1665

Jamilov, R. (2013). J-Curve dynamics and the Marshall-Lerner condition: Evidence from Azerbaijan. Transition Studies Review, 19(3), 313-323. http://dx.doi.org/10.1007/s11300-012-0240-8

Kale, P. (2001). Turkey's trade balance in the short and the long run: Error correction modeling and cointegration. The International Trade Journal, 15(1), 27-56. http://dx.doi.org/10.1080/088539001300005440

Korkmaz, S., \& Bayır, M. (2015). Döviz kuru dalgalanmalarının yurtiçi fiyatlara etkisi. Niğde Üniversitesi İktisadi ve İdari Bilimler Fakültesi Dergisi, 8(4), 69-85.

Lal, A. K., \& Lowinger, T. C. (2002). The J-Curve: Evidence from East Asia. Journal of Economic Integration, 17(June), 397-415.

Magee, S. P. (1973). Currency contracts, pass-through, and devaluation. Brookings Papers on Economic Activity, $4(1)$.

Mahdavi, S. (2000). Do German, Japanese, and U.S. export prices asymmetrically respond to exchange rate changes? Evidence from aggregate data. Contemporary Economic Policy, 18(1), 70-81. http://dx.doi.org/10.1111/j.1465-7287.2000.tb00007.x

Narayan, P. K. (2004). New Zealand's trade balance: Evidence of the J-curve and granger causality. Applied Economics Letters, 11(6), 351-354. http://dx.doi.org/10.1080/1350485042000228187

Onafowora, O. (2003). Exchange rate and trade balance in east asia: Is there a J-curve ? Economics Bulletin, $5(18), 1-33$.

Pesaran, M. H., Shin, Y., \& Smith, R. J. (2001). Bounds testing approaches to the analysis of level relationships. Journal of Applied Econometrics, 16(3), 289-326. http://dx.doi.org/10.1002/jae.616

Rose, A. K. (1990). Exchange rates and the trade balance: Some evidence from developing countries. Economics Letters, 34(3), 271-275. http://dx.doi.org/10.1016/0165-1765(90)90130-S

Rose, A. K., \& Yellen, J. L. (1989). Is there a J-curve? Journal of Monetary Economics, 24(1), 53-68.

Schorderet, Y. (2002). A nonlinear generalization of cointegration: A note on hidden cointegration (No. 2002.03). Genève. Retrieved from http://www.unige.ch/ses/metri/

Schorderet, Y. (2003). Asymmetric cointegration (No. 2003.01). Cahiers du département d'économétrie, Faculté des sciences économiques et sociales, Université de Genève.

Shin, Y., Yu, B., \& Greenwood-Nimmo, M. (2014). Modelling asymmetric cointegration and dynamic multipliers in a nonlinear ARDL framework. In R. C. Sickles \& W. C. Horrace (Eds.), Festschrift in Honor of Peter Schmidt Econometric Methods and Applications (pp. 281-314). http://dx.doi.org/10.1007/978-1-4899-8008-3

Wilson, P., \& Tat, K. C. (2001). Exchange rates and the trade balance: The case of Singapore 1970 to 1996. Journal of Asian Economics, 12(1), 47-63. http://dx.doi.org/10.1016/S1049-0078(01)00072-0

Yazici, M., \& Ahmad, K. M. (2010). Import-content of exports and J-curve effect. Applied Economics, 42(6), 769-776. http://dx.doi.org/10.1080/00036840701720846

\section{Copyrights}

Copyright for this article is retained by the author(s), with first publication rights granted to the journal.

This is an open-access article distributed under the terms and conditions of the Creative Commons Attribution license (http://creativecommons.org/licenses/by/3.0/). 